\title{
$\underline{\text { Racial Identity and Well-Being among African Americans }}$
}

By: Michael Hughes, K. Jill Kiecolt, Verna M. Keith, David H. Demo

Hughes, M., Kiecolt, K.J., Keith, V.M., Demo, D.H. (2015). Racial Identity and Well-Being among African Americans. Social Psychology Quarterly, 78(1), 25-48.doi:

$10.1177 / 0190272514554043$

Made available courtesy of Sage Publications \& the American Sociological Association (ASA): http://dx.doi.org/10.1177/0190272514554043

****() ASA. Reprinted with permission. No further reproduction is authorized without written permission from the ASA. This version of the document is not the version of record. Figures and/or pictures may be missing from this format of the document. ***

This is an author-produced, peer-reviewed article that has been accepted for publication in Social Psychology Quarterly but has not been copyedited. The publisher-authenticated version is available at http://www.asanet.org.

\section{Abstract:}

How racial identity influences self-esteem and psychological well-being among African Americans remains unresolved due to unexplained inconsistencies in theoretical predictions and empirical findings. Using data from the National Survey of American Life $(\mathrm{N}=3,570)$, we tested hypotheses derived from social identity theory and the internalized racism perspective. Findings support social identity theory in showing that African Americans strongly identify with their group and view it very positively. In addition, those who identify more with their group and evaluate it more positively have greater self-esteem, greater mastery, and fewer depressive symptoms. However, findings also support the internalized racism perspective by showing that when group evaluation is relatively negative, racial identification is related to lower mastery and higher depressive symptoms. We conclude that both social identity theory and the internalized racism perspective are necessary for understanding how racial identity is related to self-attitudes and mental health among African Americans.

Keywords: social identity | mental health | race/ethnicity | racial identity | self and identity | identity processes

\section{Article:}

\section{Introduction}

Both stress theory (e.g., Turner and Avison 2003) and the minority stress perspective (Meyer 2003) predict that African Americans should experience poor mental health and negative selfattitudes because of exposure to structural disadvantages and other stressors. In general, though, 
African Americans' self-esteem (sense of self-worth) is high and their mental health is good (Breslau et al. 2006; Gray-Little and Hafdahl 2000; Kessler et al. 1994; Kiecolt, Hughes, and Keith 2008). The findings for mastery (sense of control over one's outcomes) are similar but more mixed (Kiecolt et al. 2009; Mabry and Kiecolt 2005; Williams et al. 2012). Numerous investigators have argued that identity processes protect mental health and self-attitudes, but findings on how identity influences well-being among African Americans are inconsistent and inconclusive (e.g., Caldwell et al. 2002; Phinney 1991; Postmes and Branscombe 2002; Rosenberg 1979; Sellers et al. 2003). Theories also differ. Social identity theory predicts positive effects of racial identity on well-being (e.g., Haslam et al. 2009; Tajfel and Turner 1986), whereas the internalized racism perspective predicts negative effects (if people have internalized negative racial stereotypes, under certain conditions; e.g., Cross 1991; Rosenberg 1979; Williams and Mohammed 2013).

In the present study, we attempt to resolve these inconsistencies by testing predictions from social identity theory and the internalized racism perspective. Social identity theory assumes that people's social identity is derived from their memberships in groups and social categories. People are motivated to achieve a positive social identity that maintains or improves positive self-esteem (Tajfel 1978; Tajfel and Turner 1986). Researchers have extended the theory and predicted that a positive social identity will also improve mastery and mental health (Deaux 1993; Hogg and Abrams 1990; Outten et al. 2009). Social identity theory predicts that if people belong to a low-status group whose position in society is relatively stable and whose boundaries are relatively impermeable, they will meet the challenge of attaining a positive social identity by producing and internalizing positive ingroup definitions through a process of social creativity(Ellemers and Haslam 2012; Ellemers, Kortekaas, and Ouwerkerk 1999; Tajfel and Turner 1986). Social identity theory thus predicts that African Americans will have a positive social identity that promotes self-esteem, mastery, and good mental health. However, it is unclear what happens if social creativity fails and people internalize a negative social identity. The internalized racism perspective examines this question and predicts that cultural racism and pervasive racial stereotypes increase the likelihood that African Americans will internalize a negative social identity that leads to low self-esteem, impaired mastery, and poor mental health.

We attempt to reconcile the contrasting predictions and explanations of social identity theory and the internalized racism perspective by investigating the association between racial identity and well-being among African Americans using data from the National Survey of American Life (NSAL). The NSAL includes indicators of racial identification (closeness), positive social identity (group evaluation), self-esteem, mastery, and depressive symptoms (depressed affect, sadness, hopelessness, poor concentration, apathy, inability to enjoy life, and lack of energy; Radloff 1977). Our analysis shows that racial identity is an important element in African American life that promotes and protects well-being. At the same time, however, identity processes have the potential to undermine well-being.

\section{Literature Review}




\section{Social Identity Theory}

Social identity theory is a multifaceted social psychological theory of how people's selfconceptions as members of social groups influence intergroup behavior and group processes. It deals with cognitive, motivational, interactional, and macrosocial aspects of group life (Ellemers and Haslam 2012; Hogg 2006). Although it was developed largely to understand intergroup processes, social identity theory is grounded in assumptions about individuals' motives and behavior, and it has implications for understanding how groups and categories influence individuals' behavior and psychological outcomes. Our study uses core assumptions and principles of social identity theory to investigate how racial identity is related to well-being among African Americans. Two main ideas guide the analysis: (1) that group identification is associated with positive group evaluation and (2) that racial identification and ingroup evaluation are linked to higher self-esteem and by extension to higher mastery and lower symptoms of depression.

\section{Social identities and group evaluation}

In social identity theory, a social identity is a person's awareness of belonging to a social category or group, together with the value and emotional significance of belonging (Tajfel 1978). Social identity theorists emphasize three distinct but related aspects of social identity: selfcategorization, a cognitive component; affective commitment, an emotional component; and group self-esteem, an evaluative component (Ellemers et al. 1999). Self-categorization involves identifying as a group member and assessing oneself as being more or less typical of or similar to the group (Ashmore, Deaux, and McLaughlin-Volpe 2004). ${ }^{1}$ Affective commitment involves having strong ties to or a sense of closeness to a group or a sense of interconnection with the group (Ashmore et al. 2004; Ellemers et al. 1999). These two aspects of social identity are connected, as self-categorization as a group member must precede feeling connected and committed to a group (Ellemers and Haslam 2012). Measures of racial identification often combine them into a measure of closeness, which indexes perceived similarity and attachment to one's racial group (e.g., Ida and Christie-Mizell 2012).

Group self-esteem involves relatively positive or negative evaluations of or attitudes toward one's group. Social identity theory originally argued that group members strive to achieve or maintain a positive social identity and do so largely by making evaluative distinctions (social comparisons) that favor their ingroup over relevant outgroups (Tajfel and Turner 1986). Later research, however, has found that ingroup identification is not consistently related to ingroup bias or negativity toward outgroups (Brewer 2007; Hinkle and Brown 1990). In studies that have measured both ingroup bias and positive ingroup ratings, group identification is more strongly related to positive ingroup ratings alone (Hinkle et al. 1989; Jackson 2002; Jackson and Smith 1999). 
In research on racial identity, the evaluative aspect of social identity has been termed private regard (Sellers et al. 1998), racial self-esteem (Hughes and Demo 1989), or group evaluation (Ida and Christie-Mizell 2012). It has been measured by endorsement of positive and negative ingroup stereotypes (e.g., Hughes and Demo 1989) or happiness with or pride in an identity (Ashmore et al. 2004; Ellemers et al. 1999).

These key aspects of social identity — self-categorization, commitment, and evaluation - are distinct but related. Both theory (e.g., Tajfel and Turner 1986) and research (e.g., Ellemers et al. 1999) indicate that group identification (self-categorization and affective commitment) should be related to positive group evaluation. The linkage may be problematic for African Americans, given their status in American society. That is, members of high-status groups, assumed by social consensus to have positive characteristics, should have no difficulty evaluating their group more favorably than outgroups. Members of devalued or stigmatized groups, such as racial minority groups, must work harder to find evaluative distinctions that elevate their group's standing relative to other groups (Stets and Burke 2000; Tajfel and Turner 1986).

Social identity theory suggests that low-status groups use various strategies for attaining a positive social identity. First, individual mobility entails escaping or disaffiliating from one's group and joining a higher-status group. People tend to use this strategy when they view group boundaries as relatively permeable and stable. That is, individual success is possible despite their group's durable lower status (Ellemers and Haslam 2012). As racial group boundaries are relatively impermeable for African Americans, this strategy is not feasible for most people. Second, people may pursue social competition to improve their group's material or legal standing in society when boundaries are impermeable, but the group's lower status is relatively unstable. African Americans have used this strategy to improve their status in American society, but because of the relative stability of their racial status, progress has been slow and difficult to achieve.

Under these circumstances, to generate a positive social identity, African Americans are most likely to turn to social creativity, in which group members make favorable social comparisons by claiming positive characteristics for their group or disavowing negative ones (Ellemers and Haslam 2012; Tajfel and Turner 1986). Members of devalued groups tend to use social creativity when group boundaries seem impermeable and stable - that is, when disaffiliation is impossible, their group has restricted opportunities, and their group's status is slow or unlikely to improve. These circumstances largely characterize African Americans' situation in American society.

Social creativity strategies abound (Blanz et al. 1998). People may redefine their group's characteristics as positive (e.g., "black is beautiful”), limit intergroup comparisons to characteristics on which their group compares favorably, or change their comparison groups to outgroups to which their group compares favorably (Tajfel and Turner 1986; Thoits and Virshup 1997). Alternatively, people may assess their ingroup relative to itself at other times or relative to socially shared standards or ideals rather than against an outgroup (Blanz et al. 1998; Hogg and 
Abrams 1990). ${ }^{2}$ Assuming that social creativity succeeds, members of a devalued group will evaluate their group positively.

Thus, social identity theory would predict that despite the persistence of institutionalized racism, racial identification will be positively related to group evaluation among African Americans. Previous research indicates that among African Americans, closer identification with their racial group is associated with more positive (or less negative) group evaluation (Brown, Sellers, and Gomez 2002; Hughes and Demo 1989; Rowley et al. 1998). Hence, our first hypothesis is that:

- Hypothesis 1: The more closely African Americans identify with their group, the more positively they will evaluate it.

\section{Social identities and self-esteem}

The self-esteem hypothesis in social identity theory proposes that people are motivated to attain a positive group identity to maintain or enhance their self-esteem. That is, having a positive social identity is a means of achieving a satisfactory self-concept (Tajfel 1974; cited in Abrams and Hogg 1988). This hypothesis has been controversial for various reasons (Abrams and Hogg 1988; Brown 2000; Hogg 2006; Rubin and Hewstone 1998). Most pertinent here, the hypothesis seems to entail two opposing propositions, articulated as two corollaries by Abrams and Hogg (1988). Corollary one is that making evaluative distinctions that favor one's group leads to a more positive social identity and thus to higher self-esteem. Corollary two is that people with low self-esteem make biased evaluative distinctions to attain a positive social identity. In short, it is unclear whether self-esteem is the independent variable or the dependent variable in relation to group identification and intergroup behavior (Abrams and Hogg 1988). While findings on this question have not been fully consistent (Ellemers and Haslam 2012), more evidence supports corollary one, that self-esteem results from group identification processes (Brown 2000; Hogg 2006; Houston and Andreopoulou 2003; Rubin and Hewstone 1998).

Based on these conclusions and core arguments in social identity theory that group identification and group evaluation promote self-esteem, we expect to observe this association among African Americans. Research on African Americans supports this prediction, showing that both stronger racial identification and positive ingroup evaluation are related to higher self-esteem (Brown et al. 2002; Postmes and Branscombe 2002; Rowley et al. 1998; Vandiver et al. 2002; Williams et al. 2012). In addition, extensions of the theory also would predict benefits for mastery and mental health.

\section{Social identities and mastery}

Scholars have long contended that social identities may help satisfy needs other than self-esteem (e.g., Deaux 1993; Hogg and Abrams 1990). One of these is the need for self-efficacy or mastery, a sense of control over one's outcomes. ${ }^{3}$ Hogg and Abrams (1990:45) proposed that enacting social identities in socially valued contexts promotes a sense of self-efficacy. This 
prediction was supported in a study of combined individual-, relational-, and group-level identities (Vignoles et al. 2006). Stronger racial or ethnic identification is related to higher mastery (Hughes and Demo 1989; Smith and Silva 2011). Importantly, social identities may promote mastery even in the absence of favorable intergroup social comparisons; instead, "comparisons with one's group in the past, or with some ideal state may be just as relevant" (Hogg and Abrams 1990:45). Consistent with earlier findings (Hughes and Demo 1989), we expect positive group evaluation, along with group identification, to be related to higher mastery among African Americans.

\section{Social identities and mental health}

Social identity theory was not designed to help explain mental health outcomes. However, recent work suggests that group identification is related to better mental health outcomes (e.g., Branscombe, Schmitt, and Harvey 1999; Haslam et al. 2005; reviewed by Haslam et al. 2009), such as lower depressive symptoms. The mechanism is not positive social comparisons, but the social support that group affiliation can provide (Haslam et al. 2005, 2009). A metaanalysis found that ethnic identity was less strongly related to mental health symptoms such as distress than to self-esteem (Smith and Silva 2011). Nevertheless, for African Americans, stronger racial identification and positive group evaluation are related to lower depressive symptoms (Ida and Christie-Mizell 2012).

Based on social identity theory and the literature reviewed previously on self-esteem, mastery, and depressive symptoms we predict that:

- Hypotheses 2a-c: Among African Americans, closer group identification will be related to (a) greater self-esteem, (b) greater mastery, and (c) fewer depressive symptoms.

- Hypotheses 3a-c: Among African Americans, more favorable ingroup evaluation will be related to (a) greater self-esteem, (b) greater mastery, and (c) fewer depressive symptoms.

In summary, social identity theory explains how group identification promotes a positive social identity that leads to or maintains positive self-esteem and, by extension, mastery and positive psychological well-being. As noted previously, the theory argues that when a social identity is negative, people pursue strategies to attain a positive social identity. Research on negative social identities has sought to explain what strategies people use to promote or protect a positive social identity. For example, studies have examined how structural characteristics (e.g., stability of group status and permeability of group boundaries) affect the strategies low-status groups employ to promote a more positive social identity (Blanz et al. 1998; Mummendey et al. 1999). But what happens when such strategies fail? In particular, what happens to self-esteem, mastery, or psychological well-being when people negatively evaluate and identify with groups whose boundaries are relatively impermeable and whose low status is relatively stable? Social identity theory, which focuses mostly on intergroup processes, has little to say about this issue. The 
concept of internalized racism has been used by researchers in psychology and sociology to address this question.

\section{The Internalized Racism Perspective}

Internalized racism involves accepting the negative racial stereotypes of minority groups that pervade society and applying them to oneself as a group member (Williams and Mohammed 2013). Early social psychologists assumed that this phenomenon was widespread and that it damaged self-esteem. Work from the 1940s through the 1960s (e.g., Clark and Clark 1947; Kardiner and Ovesey 1951; Lewin 1948; Proshansky and Newton 1968) argued that members of devalued or stigmatized minority groups internalized negative cultural stereotypes of their groups and that as a result, members disliked their groups, wanted to join the dominant group (which rejected them), and experienced low self-esteem and other forms of demoralization. Some scholars viewed this problem as especially serious for African Americans, who were trapped by their ascribed status in a group they viewed negatively (Clark and Clark 1947; Kardiner and Ovesey 1951; Proshansky and Newton 1968).

Recent research on stigmatization and minority stress supports earlier arguments about internalization of negative stereotypes. When members of a stigmatized group know their group is devalued and feel unfairly excluded from mainstream society, they have more distress and thus poorer mental and physical health (Meyer 2003; Stuber, Meyer, and Link 2008). Similarly, awareness or acceptance of negative stereotypes of the ingroup undermines well-being and effective performance in a variety of contexts (Levy et al. 2009; Link 1987; Steele 1997).

Revisionist scholarship in the 1970s and 1980s challenged the assumption that minority status resulted in poor self-esteem and well-being by showing that being black had no systematic impact on self-esteem or other dimensions of well-being (Rosenberg and Simmons 1972; Yancey, Rigsby, and McCarthy 1972). Researchers reasoned that racial identity and what they termed "personal identities," particularly self-esteem, are distinct self-concept elements, arising from different social processes (Cross 1991; Porter and Washington 1979). ${ }^{4}$ Blacks' selfesteem, they concluded, is most influenced by their reference groups - family and friendship groups comprised mostly of other blacks and not by the wider, largely white, society (McCarthy and Yancey 1971; Rosenberg and Simmons 1972; Yancey et al. 1972). In addition, racial identity exists alongside many other dimensions of the self-concept, such as ego-extensions and personal characteristics, so its relative impact on self-esteem is small (Cross 1991; Rosenberg 1979).

Rosenberg's (1979) study of Baltimore school children supported these ideas by showing that racial group attachment (an indicator of racial identity) had no overall association with selfesteem. However, black children who internalized the group into their self-concept and lacked pride in their racial group had low self-esteem. But this phenomenon was rare (occurring in 
roughly 3 percent of respondents). Otherwise, racial identification had little, if any, association with self-esteem.

Influential theory and research on nigresence, a process of accepting and affirming a black identity in American society (Cross 1991; Vandiver 2001), largely supports Rosenberg's (1979) findings. Most of the many dimensions of black identity (Cross 1971, 1991; Vandiver et al. 2002) are unrelated to self-esteem and well-being. In contrast, the dimension of "miseducation" (endorsing negative stereotypes about African Americans) diminishes well-being if it is internalized and transformed into self-hatred for being black (Vandiver et al. 2002). That black college students rarely endorse negative ingroup stereotypes or indicators of self-hatred for being black (Vandiver et al. 2002) implies that internalized racism should have little overall impact on most African Americans' feelings of self-worth, mastery, or depressive symptoms. ${ }^{5}$

Early and revisionist studies of internalized racism largely agree, except on one point. Earlier studies of small samples of African Americans showed some evidence of outgroup preferences and/or negative ingroup evaluation. Researchers assumed that these elements were widespread and internalized and that they led to low self-esteem and poor psychological outcomes (reviewed by Cross 1991). ${ }^{6}$ Later studies (Rosenberg 1979; Vandiver et al. 2002) showed that internalized racism damages self-esteem and well-being, but for most African Americans, racial identity is positive and internalization of negative racial stereotypes is rare. ${ }^{7}$ Based on the internalized racism perspective, we predict that:

- Hypotheses 4a-c: Group identification and group evaluation will interact. For African Americans who evaluate their group negatively (that is, accept negative racial stereotypes), greater closeness will be related to (a) lower self-esteem, (b) lower mastery, and (c) more depressive symptoms.

\section{The Problem}

In the analyses that follow, we test the hypotheses derived from social identity theory and the internalized racism perspective. These frameworks offer distinct arguments linking group identity to well-being. We aim to develop an empirically supported, theoretically integrated understanding of how group identification and ingroup evaluation affect self-attitudes and psychological well-being among African Americans.

\section{Control Variables}

The analyses control for the quality of respondents' social relationships, perceptions of racial discrimination, and social characteristics. Racial identity develops and is sustained in social relationships. As Deaux and Martin (2003:106) have argued, membership in a social category "provides not only a label but also a potential network of other persons who share that membership." African Americans' close social relationships - with family members, friends, and 
church members - are mostly with other African Americans. Supportive social relationships should be related to a stronger, more positive racial identity. ${ }^{8}$

Social relationships also may partly explain the effects of racial identity on self-esteem, mastery, and depressive symptoms (Haslam et al. 2005, 2009). As Stets and Burke (2000:233) noted, "The increase in self-worth that accompanies a group-based identity . . may come not simply from the act of identifying with the group, but from the group's acceptance of the individual as a member." Supportive relationships enhance mastery and self-esteem; persistently unsupportive relationships undermine them (Cast and Burke 2002). Supportive and strained social relationships also are associated with depressive symptoms (e.g., Kiecolt et al. 2008; Okun and Keith 1998). Overall, controlling for social relationships will yield a purer estimate of how racial identity influences self-attitudes and depressive symptoms.

We also control for perceived racial discrimination because it is linked to lower self-esteem and mastery (Williams et al. 2012) and higher depressive symptoms (Ida and Christie-Mizell 2012; Miller, Rote, and Keith 2013; Sellers et al. 2003), as well as to racial identity. Discrimination may lead minority group members to identify more with their group to alleviate the adverse effects on well-being of rejection by a dominant group (the rejection-identification hypothesis; Branscombe et al. 1999; Ramos et al. 2012). Conversely, a stronger racial identity increases awareness of discrimination (Sellers and Shelton 2003), in line with Thoits's (2013) identity-relevant stressor hypothesis.

The analysis also controls for several demographic characteristics. Age is positively related to identification with other African Americans (Harris 1995) and to mastery (Hughes and Demo 1989). Women have lower mastery (Hughes and Demo 1989) and higher distress (e.g., Kiecolt et al. 2008) than men do. More educated African Americans feel less close to other African Americans (Broman, Neighbors, and Jackson 1988) but evaluate African Americans as a group more positively (Hughes and Demo 1989). Education and income are related to higher mastery (Hughes and Demo 1989) and lower psychological distress (Kiecolt et al. 2008). Married or partnered people have lower distress (e.g., Kiecolt et al. 2008).

\section{Methods}

\section{Data}

The data for this study came from the National Survey of American Life (NSAL; Alegria et al. 2007; Jackson et al. 2006), administered from 2001 to 2003 by the University of Michigan's Institute for Social Research Survey Research Center. The survey was a national multistage probability sample of 6,082 noninstitutionalized adults aged 18 and older in the continental United States. Data were collected using face-to-face computer-assisted interviews. The response rate was 72.3 percent overall and 70.7 percent for African Americans. The sample we analyze is of 3,570 African American respondents. The survey also included a sample of Caribbean blacks who were of West Indian or Caribbean descent. We chose not to include these respondents 
because most were immigrants or children of immigrants, and the issue of immigration raises theoretical and empirical issues (Montazer and Wheaton 2011; Mossakowski 2007) that go beyond the scope of the present study. Sampling weights adjusted for differential probability of inclusion (Heeringa et al. 2006). Standard errors of test statistics were adjusted for survey design effects using Stata12 (StataCorp 2011).

\section{Measures}

\section{Dependent variables}

The analysis had three dependent variables. Rosenberg's self-esteem scale (1989) averaged scores on 10 items $(\alpha=.76)$. Example items were "I feel that I have a number of good qualities" and "I feel I do not have much to be proud of." Responses were $3=$ very true, 2 = somewhat true, $1=$ a little true, or $0=$ not true at all. Items were coded so that higher values meant higher self-esteem. The scale ranged from 0 to 3 .

The mastery scale (Pearlin and Radabaugh 1976) had seven items $(\alpha=.72)$. Example items were "There is really no way I can solve some of the problems I have" and "I can do just about anything I set my mind to." Responses were $0=$ strongly agree, 1 = agree, 2 = disagree, or $3=$ strongly disagree. The items were coded so that higher values meant higher mastery, and scores were averaged. The scale ranged from 0 to 3 .

Depressive symptomatology was measured by a 12-item version of the Center for Epidemiological Studies Depression Index (CES-D; Radloff 1977): "Please tell me how often you have felt this way during the past week. ___ " " (1) I felt as good as other people, (2) I had trouble keeping my mind on what I was doing, (3) I felt depressed, (4) I felt that everything I did was an effort, (5) I felt hopeful, (6) my sleep was restless, (7) I felt happy, (8) people were unfriendly, (9) I enjoyed life, (10) I had crying spells, (11) I felt that people disliked me, and (12) I could not get "going." Responses ranged from $0=$ rarely or none of the time to $3=$ most or all of the time. Items were coded so that higher scores signified more depressive symptoms. The index ranged from 0 to $36(\alpha=.76)$.

\section{Independent variables}

We analyzed two aspects of racial identity. ${ }^{9}$ Closeness to African Americans was a nine-item index $(\alpha=.87)$. Respondents were asked, "How close do you feel in your ideas and feelings about things to ": black people; black people who are poor; religious, church-going black people; young black people; upper-class black people; black elected officials; working-class black people; black doctors, lawyers, and other black professional people; and older black people? Response categories were very close, fairly close, not too close, or not close at all. As the latter two categories had only a small percentage of respondents, we recoded responses as $2=$ very close, $1=$ fairly close, and $0=$ not too close or not close at all. The resulting index, which averaged scores on the items, ranged from 0 to 2 . 
A second dimension of racial identity, evaluation of African Americans as a group, was measured by a scale of positive and negative stereotypes held of African Americans.

Respondents were asked, "How true do you think it is that most black people ___ ": are intelligent, are hardworking, are proud of themselves, are lazy, give up easily, and are violent? Response categories ranged from $0=$ not at all true to $3=$ very true. Items were coded so that higher scores represented a more favorable ingroup evaluation. The scale averaged scores on the items $(\alpha=.62)$.

\section{Control variables}

We included four aspects of social relationships. Family support was a three-item index $(\alpha=.72)$ that averaged scores on how often respondents' families made them feel loved, listened to their problems, or expressed concern for their well-being ( $0=$ never to $3=$ very often). Family strain was a three-item index $(\alpha=.84)$ that averaged scores on how often respondents' families made too many demands on them, criticized them, or took advantage of them $(0=$ never to $3=$ very often). Closeness to church members was measured on a 4-point scale, from $1=$ not close at all to 4 = very close. Non-church attendees were coded 0 . Friend support was a four-item index of how often respondents saw, wrote, or talked on the telephone with friends $(1=$ never to $7=$ nearly every day); how often friends helped them out ( $1=$ never to $4=$ very often $)$; how often respondents helped their friends out $(1=$ never to $4=$ very often $)$; and how close respondents felt to their friends $(1=$ not close at all to $4=$ very close $)$. The items were rescaled and scores averaged so that the scale ranged from 0 to $3(\alpha=.81)$. Respondents without any friends were coded 0 on each item.

A ten-item index of everyday discrimination $(\alpha=.86)$ has been used in numerous studies (e.g., Ida and Christie-Mizell 2012; Williams et al. 2012). This index taps the chronic stress of discrimination, which has been shown to be more strongly linked to well-being among African Americans than measures of lifetime discrimination (Kessler, Mickelson, and Williams 1999; Williams et al. 1997). Respondents were asked, "In your day-to-day life how often have any of the following things happened to you?": you are treated with less courtesy than other people, you are treated with less respect than other people, you receive poorer service than other people at restaurants or stores, people act as if they think you are not smart, people act as if they are afraid of you, people act as if they think you are dishonest, people act as if they're better than you are, you are called names or insulted, you are threatened or harassed, or you are followed around in stores. Respondents were then asked, "What do you think was the main reason for this/these experience(s)? Would you say your ancestry or national origins, your gender, your race, your age, your height or weight, your shade of skin color, or other?" Scores were averaged for items on which respondents attributed their experiences to ancestry or national origins, race, or shade of skin color. Responses were coded $0=$ never (volunteered), $1=$ less than once a year, $2=\mathrm{a}$ few times a year, $3=\mathrm{a}$ few times a month, $4=$ at least once a week, $5=$ almost every day. The index ranged from 0 to 5. 
The models also controlled for age in years, gender $(0=$ male, $1=$ female $)$, education $(1=$ less than high school, 2 = high school degree, 3 = some college, 4 = college degree), family income in thousands of dollars, and marital status $(0=$ previously married or never married and not cohabiting, 1 = married or cohabiting). For the regression analyses, age and income were divided by 10 to eliminate regression coefficients of zero.

\section{Data Analysis}

We first generated descriptive statistics for the model variables as well as correlations among the study variables. Ordinary least squares (OLS) regression analyses investigated how racial identity influences self-esteem, mastery, and depressive symptoms. We estimated three models for each dependent variable. Model I had closeness to African Americans and evaluation of African Americans as a group as predictors, controlling for social characteristics. Model II added controls for social relationships and everyday discrimination. Model III tested whether the two dimensions of social identity interacted with each other to influence self-attitudes and depressive symptoms.

\section{Results}

Table 1 shows descriptive statistics for the study variables. Average self-esteem and mastery were high, and average depressive symptoms were low. Consistent with the assumptions of social identity theory, on average, respondents felt close to other African Americans (between fairly close and very close). Moreover, evaluation of African Americans as a group was overwhelmingly favorable, with a mean of 2.18 out of 3 . These findings are inconsistent with the assumptions of the internalized racism perspective. Further, in analyses not shown, 87.6 percent of respondents endorsed positive stereotypes more than negative stereotypes of African Americans. Only 7.5 percent of respondents endorsed positive and negative stereotypes equally, and only 5.0 percent endorsed negative stereotypes more than positive ones.

Table 1. Descriptive Statistics for Study Variables

\begin{tabular}{|l|l|l|l|l|}
\hline Variable & Mean & SE & Range & Unweighted N \\
\hline Well-being: & 2.62 & .01 & $0-3$ & 3,415 \\
\hline Self-esteem & 2.33 & .01 & $0-3$ & 3,399 \\
\hline Mastery & 6.71 & .19 & $0-36$ & 3,383 \\
\hline Depressive symptoms (CES-D) & 1.28 & .01 & $0-2$ & 3,458 \\
\hline Social identity measures: & 2.18 & .02 & $0-3$ & 3,491 \\
\hline Closeness to African Americans & 2.23 & .02 & $0-3$ & 3,530 \\
\hline Positive evaluation of African Americans & 2.02 \\
\hline Social relationships: & .84 & .02 & $0-3$ & 3,522 \\
\hline Family support & 2.45 & .03 & $0-4$ & 3,561 \\
\hline Family stress & 1.91 & .01 & $0-3$ & 3,553 \\
\hline Closeness to church members & Friend support
\end{tabular}




\begin{tabular}{|l|l|l|l|l|}
\hline Everyday racial discrimination & .89 & .03 & $0-5$ & 3,525 \\
\hline Age in years & 42.33 & .52 & $18-93$ & 3,570 \\
\hline Female & .56 & & 0,1 & 3,570 \\
\hline Married or cohabiting & .42 & & 0,1 & 3,562 \\
\hline Education (four categories) & 2.28 & .03 & $1-4$ & 3,570 \\
\hline Family income in $\$ 1,000 \mathrm{~s}$ & 36.12 & 1.31 & $0-20$ & 3,570 \\
\hline
\end{tabular}

Hypothesis 1 from social identity theory predicted that the more strongly African Americans identify with their group, the more positively they will evaluate it. As predicted, closeness to African Americans and ingroup evaluation were significantly and positively correlated with one another $(r=.16, p<.001)$ (see Table 2). Their association remained strong in a regression analysis with social relationships, everyday racial discrimination, and social characteristics controlled (analysis not shown). Thus, African Americans who had a stronger sense of racial identification evaluated African Americans more positively.

Table 2. Correlations among Study Variables: Self-Esteem, Mastery, Depressive Symptoms (CES-D), Racial Identity Variables, Social Relationships, Everyday Racial Discrimination, and Control Variables

\begin{tabular}{|c|c|c|c|c|c|c|c|c|c|c|c|c|c|c|}
\hline & $\begin{array}{l}1 . \\
\text { Self- } \\
\text { esteem }\end{array}$ & 2. & 3. & 4. & 5. & 6. & 7. & 8. & 9. & 10. & 11. & 12. & 13. & 14. \\
\hline 2. Mastery & .62 & & & & & & & & & & & & & \\
\hline 3. CES-D & -.51 & -48 & & & & & & & & & & & & \\
\hline $\begin{array}{l}\text { 4. Closeness to } \\
\text { African } \\
\text { Americans }\end{array}$ & .10 & .06 & .06 & & & & & & & & & & & \\
\hline $\begin{array}{l}\text { 5. Group } \\
\text { evaluation }\end{array}$ & .20 & .20 & .24 & .15 & & & & & & & & & & \\
\hline $\begin{array}{l}\text { 6. Family } \\
\text { support }\end{array}$ & .17 & .16 & .13 & 16 & .09 & & & & & & & & & \\
\hline $\begin{array}{l}\text { 7. Family } \\
\text { strain }\end{array}$ & -.20 & $\begin{array}{l}- \\
.21\end{array}$ & .27 & -.06 & -.15 & $\begin{array}{l}- \\
.16\end{array}$ & & & & & & & & \\
\hline $\begin{array}{l}\text { 8. Closeness to } \\
\text { church } \\
\text { members }\end{array}$ & .13 & .07 & -.11 & .22 & $.02^{\mathrm{a}}$ & .14 & -.08 & & & & & & & \\
\hline $\begin{array}{l}\text { 9. Friend } \\
\text { support }\end{array}$ & .13 & .11 & .08 & .14 & .06 & .26 & $.02^{\mathrm{a}}$ & .13 & & & & & & \\
\hline $\begin{array}{l}\text { 10. Everyday } \\
\text { discrimination }\end{array}$ & -.13 & -.14 & .21 & $-.01^{\mathrm{a}}$ & $.01^{\mathrm{a}}$ & .07 & .21 & $\begin{array}{l}- \\
.07\end{array}$ & $.00^{\mathrm{a},}$ & & & & & \\
\hline 11. Age & $-.04 \mathrm{a}$ & $\begin{array}{l}- \\
.11 \\
\end{array}$ & $\begin{array}{l}- \\
.15 \\
\end{array}$ & .10 & $\begin{array}{l}- \\
.02 \mathrm{a} \\
\end{array}$ & $\begin{array}{l}- \\
.07 \\
\end{array}$ & -.19 & .17 & -.11 & -.15 & & & & \\
\hline 12. Female & $-.01 \mathrm{a}$ & $\begin{array}{l}- \\
.06\end{array}$ & .09 & $.00^{\mathrm{a},}$ & -.05 & .08 & .09 & .10 & $.02^{\mathrm{a}}$ & -.12 & $.02^{\mathrm{a}}$ & & & \\
\hline
\end{tabular}




\begin{tabular}{|c|c|c|c|c|c|c|c|c|c|c|c|c|c|c|}
\hline $\begin{array}{l}\text { 13. Married or } \\
\text { cohabiting }\end{array}$ & .11 & .08 & $\begin{array}{l}- \\
.08\end{array}$ & $.01^{\mathrm{a}}$ & $.01^{\mathrm{a}}$ & $.03^{\mathrm{a}}$ & $-02^{\mathrm{a}}$ & .09 & -.09 & $.00^{\mathrm{a}, \mathrm{b}}$ & .08 & - & & \\
\hline 14. Education & .24 & .24 & .23 & $-.02^{\mathrm{a}}$ & .20 & $.04^{\mathrm{a}}$ & $\begin{array}{l}- \\
.00^{\mathrm{a}}, \\
\mathrm{b}\end{array}$ & .04 & .07 & .06 & -.07 & $.01^{\mathrm{a}}$ & .10 & \\
\hline $\begin{array}{l}\text { 15. Household } \\
\text { income }\end{array}$ & .21 & .20 & $\begin{array}{l}- \\
.20\end{array}$ & $.01^{\mathrm{ab}}$ & .10 & $.04^{\mathrm{a}}$ & $\begin{array}{l}- \\
03^{\mathrm{a}}\end{array}$ & .05 & $.03^{\mathrm{a}}$ & $.05^{\mathrm{a}}$ & $.01^{\mathrm{a}}$ & -15 & .34 & .40 \\
\hline
\end{tabular}

${ }^{\mathrm{a} C}$ Correlation is not significant. Correlations not so noted are significant at $\mathrm{p}<.05$ or less.

${ }^{\mathrm{b}}$ Absolute value of correlation is $<.005$.

Based on social identity theory, Hypotheses $2 \mathrm{a}, 2 \mathrm{~b}$, and $2 \mathrm{c}$ predicted that racial identification with African Americans would be positively associated with self-esteem and mastery and negatively associated with depressive symptoms, respectively. The significant correlations $(p<$ $.05)$ of closeness to self-esteem $(r=.10)$, mastery $(r=.06)$, and depressive symptoms $(r=-.06)$ shown in Table 2 support all three parts of Hypothesis 2. Similarly, Table 2 shows that as Hypotheses 3a, 3b, and 3c predicted, a more positive evaluation of African Americans was significantly correlated $(p<.05)$ with higher self-esteem $(r=.20)$ and mastery $(r=.20)$ and lower depressive symptoms $(r=-.24)$.

Table 3 reports findings from the regressions of self-esteem, mastery, and depressive symptoms on racial identity and the control variables. The Model I analyses show that with social characteristics controlled, both closeness and positive evaluation of African Americans were associated with higher self-esteem and mastery. For depressive symptoms, when both closeness and group evaluation were included as predictors, closeness to African Americans was not significant. This is because its association with depressive symptoms was mediated by group evaluation. In analyses not shown, with only social characteristics controlled, closeness significantly reduced depressive symptoms $(b=-.54, p<.05)$.

Table 3. Unstandardized Coefficients from Regressions of Self-Esteem, Mastery, and Depressive Symptoms (CES-D) on Measures of Social Identity, Social Relationships, Everyday Discrimination, and Social Characteristics ${ }^{\mathrm{a}}$

\begin{tabular}{|c|c|c|c|c|c|c|c|c|c|}
\hline & \multicolumn{3}{|c|}{ Self-Esteem } & \multicolumn{3}{|c|}{ Mastery } & \multicolumn{3}{|c|}{$\begin{array}{c}\text { Depressive Symptoms } \\
\text { (CES-D) }\end{array}$} \\
\hline & I & II & III & I & II & III & I & II & III \\
\hline \multicolumn{10}{|c|}{ Social identity measures: } \\
\hline $\begin{array}{l}\text { Closeness to } \\
\text { African } \\
\text { Americans }\end{array}$ & $\begin{array}{l}.07 * * * \\
(.02)\end{array}$ & $\begin{array}{l}.04 * * \\
(.01)\end{array}$ & $\begin{array}{l}-.05 \\
(.06)\end{array}$ & $\begin{array}{l}.05^{*} \\
(.02)\end{array}$ & $\begin{array}{l}.01 \\
(.02)\end{array}$ & $\begin{array}{l}-.18^{*} \\
(.07)\end{array}$ & $\begin{array}{l}-.17 \\
(.26)\end{array}$ & $\begin{array}{l}.16 \\
(.24)\end{array}$ & $\begin{array}{l}2.96^{*} \\
(1.16)\end{array}$ \\
\hline $\begin{array}{c}\text { Positive } \\
\text { evaluation } \\
\text { of African } \\
\text { Americans }\end{array}$ & $\begin{array}{l}.12 * * * \\
(.02)\end{array}$ & $\begin{array}{l}.09 * * * \\
(.02)\end{array}$ & $\begin{array}{l}.03 \\
(.04)\end{array}$ & $\begin{array}{l}18 * * * \\
(.02)\end{array}$ & $\begin{array}{l}.13 * * * \\
(.02)\end{array}$ & $\begin{array}{l}.01 \\
(.06)\end{array}$ & $\begin{array}{c}- \\
2.32 * * * \\
(.25)\end{array}$ & $\begin{array}{c}- \\
1.89^{* * * *} \\
(.27)\end{array}$ & $\begin{array}{l}-.17 \\
(.66)\end{array}$ \\
\hline $\begin{array}{l}\text { Closeness } x \\
\text { positive } \\
\text { evaluation }\end{array}$ & & & $\begin{array}{l}.04 \\
(.03)\end{array}$ & & & $\begin{array}{l}.09^{*} \\
(.04)\end{array}$ & & & $\begin{array}{c}-1.32^{*} \\
(.51)\end{array}$ \\
\hline \multicolumn{10}{|c|}{ Social relationships } \\
\hline
\end{tabular}




\begin{tabular}{|c|c|c|c|c|c|c|c|c|c|}
\hline $\begin{array}{l}\text { Family } \\
\text { support }\end{array}$ & & $\begin{array}{l}.04 * * \\
(.01)\end{array}$ & $\begin{array}{l}.04 * * \\
(.01)\end{array}$ & & $\begin{array}{l}.06 * * * * \\
(.02)\end{array}$ & $\begin{array}{c}.06^{* * * *} \\
(.02)\end{array}$ & & $\begin{array}{c}.38 * * \\
(.14)\end{array}$ & $\begin{array}{c}-.38 * * \\
(.14)\end{array}$ \\
\hline $\begin{array}{c}\text { Family } \\
\text { stress }\end{array}$ & & $\begin{array}{c}-.08 * * * \\
(.01)\end{array}$ & $\begin{array}{c}-.08 * * * \\
(.01)\end{array}$ & & $\begin{array}{c}- \\
.13 * * *(.0 \\
2)\end{array}$ & $\begin{array}{c}.13^{* * * *}(.0 \\
2)\end{array}$ & & $\begin{array}{c}1.28 * * * \\
(.17)\end{array}$ & $\begin{array}{c}1.27 * * \\
* \\
(.17)\end{array}$ \\
\hline $\begin{array}{l}\text { Closeness to } \\
\text { church } \\
\text { members }\end{array}$ & & $\begin{array}{c}.02 * *(.01 \\
)\end{array}$ & $\begin{array}{c}.02 * * *(.0 \\
1)\end{array}$ & & $\begin{array}{l}.02^{*} \\
(.01)\end{array}$ & $\begin{array}{l}.02^{*} \\
(.01)\end{array}$ & & $\begin{array}{l}-.17 * \\
(.06)\end{array}$ & $\begin{array}{c}.17 * \\
(.06)\end{array}$ \\
\hline $\begin{array}{l}\text { Friend } \\
\text { support }\end{array}$ & & $\begin{array}{c}.04 * * *(.0 \\
1)\end{array}$ & $\begin{array}{c}.04 * * *(.0 \\
1)\end{array}$ & & $\begin{array}{l}.03 * * \\
(.01)\end{array}$ & $\begin{array}{l}.04 * * \\
(.01)\end{array}$ & & $\begin{array}{c}-.41 * * \\
(.13) \\
\end{array}$ & $\begin{array}{c}-.41 * * \\
(.13) \\
\end{array}$ \\
\hline $\begin{array}{c}\text { Everyday } \\
\text { racial } \\
\text { discriminati } \\
\text { on }\end{array}$ & & $\begin{array}{c}-.05^{* * * *} \\
(.01)\end{array}$ & $\begin{array}{c}.05 * * * \\
(.01)\end{array}$ & & $\begin{array}{l}.01 * * * \\
(.00)^{\mathrm{a}}\end{array}$ & $\begin{array}{c}.01^{* * *} \\
(.00)^{\mathrm{a}}\end{array}$ & & $\begin{array}{c}.10 * * * \\
(.01)\end{array}$ & $\begin{array}{c}.10^{* * * *} \\
(.01)\end{array}$ \\
\hline \multicolumn{10}{|c|}{ Social characteristics } \\
\hline $\begin{array}{l}\text { Age in } \\
\text { decades }\end{array}$ & $\begin{array}{l}-.01^{*} \\
(.01)\end{array}$ & $\begin{array}{c}-.02 * * * * \\
(.01)\end{array}$ & $\begin{array}{c}.02 * * * \\
(.01)\end{array}$ & $\begin{array}{c}- \\
.04 * * * \\
\mathrm{a} \\
(.00)^{\mathrm{b}}\end{array}$ & $\begin{array}{c}-.01 * * * \\
(.00)^{\mathrm{b}}\end{array}$ & $\begin{array}{c}.06 * * * \\
(.00)^{\mathrm{b}}\end{array}$ & $\begin{array}{c}-.56^{* * * *} \\
(.06)\end{array}$ & $\begin{array}{c}-.06 * * * \\
(.01)\end{array}$ & $\begin{array}{c}- \\
.06^{* * *} \\
(.01)\end{array}$ \\
\hline Female & $\begin{array}{l}.01 \\
(.02)\end{array}$ & $-.00^{\mathrm{a}}(.02)$ & $\begin{array}{l}-.00^{\mathrm{b}} \\
(.02)\end{array}$ & $\begin{array}{l}.04 \\
(.02)\end{array}$ & $\begin{array}{c}-.06^{* * *} \\
(.02)\end{array}$ & $\begin{array}{c}-.06 * * \\
(.02)\end{array}$ & $\begin{array}{c}.78 * * * \\
(.21)\end{array}$ & $\begin{array}{c}.88^{* * * *} \\
(.19)\end{array}$ & $\begin{array}{c}.88^{* * * *} \\
(.19)\end{array}$ \\
\hline $\begin{array}{l}\text { Married or } \\
\text { cohabiting }\end{array}$ & $\begin{array}{c}.04 \\
(.02)\end{array}$ & $\begin{array}{l}.04^{*} \\
(.02)\end{array}$ & $\begin{array}{l}.04 * \\
(.02)\end{array}$ & $\begin{array}{c}.03 \\
(.02)\end{array}$ & $\begin{array}{l}.03 \\
(.02)\end{array}$ & $\begin{array}{l}.03 \\
(.02)\end{array}$ & $\begin{array}{l}.12 \\
(.25)\end{array}$ & $\begin{array}{l}.18 \\
(.24)\end{array}$ & $\begin{array}{c}.18 \\
(.24)\end{array}$ \\
\hline Education & $\begin{array}{c}.07 * * * \\
(.01)\end{array}$ & $\begin{array}{c}.07 * * * \\
(.01)\end{array}$ & $\begin{array}{c}.07 * * * \\
(.01)\end{array}$ & $\begin{array}{c}.09 * * * \\
(.01)\end{array}$ & $\begin{array}{c}.10 * * * \\
(.01)\end{array}$ & $\begin{array}{c}.10 * * * \\
(.01)\end{array}$ & $\begin{array}{c}-.95^{* * * *} \\
(.14)\end{array}$ & $\begin{array}{c}- \\
1.17^{* * * *} \\
(.12)\end{array}$ & $\begin{array}{c}- \\
1.17 * * \\
* \\
(.12)\end{array}$ \\
\hline $\begin{array}{l}\text { Family } \\
\text { income } \\
(\$ 10,000)\end{array}$ & $\begin{array}{l}.01 * * * \\
(.00)^{\mathrm{b}}\end{array}$ & $\begin{array}{l}.01 * * * \\
(.00)^{\mathrm{b}}\end{array}$ & $\begin{array}{l}.01 * * * \\
(.00)^{\mathrm{b}}\end{array}$ & $\begin{array}{l}.00^{* * * *} \\
\mathrm{~b}(.00)^{\mathrm{b}}\end{array}$ & $\begin{array}{c}.00 * * * \mathrm{~b} \\
(.00)^{\mathrm{b}}\end{array}$ & $\begin{array}{l}.02 * * * * \\
(.00)^{\mathrm{b}}\end{array}$ & $\begin{array}{c}-.19^{* * * *} \\
(.00)^{\mathrm{b}}\end{array}$ & $\begin{array}{c}-.02 * * * \\
(.00)^{\mathrm{b}}\end{array}$ & $\begin{array}{c}- \\
.02 * * * \\
(.00)^{\mathrm{b}}\end{array}$ \\
\hline Constant & $\begin{array}{c}2.28 * * \\
*\end{array}$ & $2.43 * * *$ & $2.54 * * *$ & $\begin{array}{c}1.89^{* *} \\
*\end{array}$ & $2.04 * * *$ & $2.29 * * *$ & $\begin{array}{c}11.99 * * \\
*\end{array}$ & $\begin{array}{c}10.60 * * \\
*\end{array}$ & $\begin{array}{c}7.40^{* *} \\
*\end{array}$ \\
\hline $\mathrm{R}^{2}$ & .11 & .18 & .18 & .11 & .19 & .19 & .14 & .23 & .23 \\
\hline $\mathrm{N}$ & 3,218 & 3,218 & 3,218 & 3,208 & 3,208 & 3,208 & 3,216 & 3,216 & 3,216 \\
\hline
\end{tabular}

${ }^{\mathrm{a}}$ All predictor variables are centered except for interaction terms and component variables of interaction terms. ${ }^{b}$ Absolute value of the coefficient is less than $.005 . * p<.05 . * * p<.01$. $* * * \mathrm{p}<.001$ (two-tailed tests).

Model II added the social relationship variables and everyday racial discrimination. Adding these variables reduced the effect of closeness on self-esteem by 43 percent, from $b=.07(p<.001)$ to $b=.04(p<.01)$ and the effect of group evaluation by 25 percent, from $b=.12(p<.001)$ to $b=.09(p<.001)$. For mastery, the effect of closeness decreased by 80 percent, from $b=.05$ $(p<.05)$ to $b=.01(p>.10)$. For depressive symptoms, the coefficient for group evaluation was reduced by 19 percent, from $b=-2.32(p<.001)$ to $b=-1.89(p<.001)$.

The changes in the coefficients for closeness and group evaluation were due solely to adding the social relationship variables. In contrast, adding everyday racial discrimination did not alter any of the coefficients for racial identity. Neither dimension of racial identity was associated with everyday racial discrimination $(r=-.03, p>.10$ for closeness and $r=-.03, p>.10$ for group evaluation; see Table 2). ${ }^{10}$ In models for self-esteem, mastery, and depressive symptoms like 
those of Model II but without discrimination, the coefficients for closeness and group evaluation were unchanged (analyses not shown).

The Model III analyses in Table 3 added the interactions of closeness $\times$ group evaluation. These interactions test Hypotheses $4 \mathrm{a}, 4 \mathrm{~b}$, and $4 \mathrm{c}$ from the internalized racism perspective that for African Americans who evaluate their group negatively, identifying more closely with their group will be related to (a) lower self-esteem and (b) lower mastery and (c) higher depressive symptoms, respectively. For self-esteem, the interaction term was not significant. Thus, Hypothesis 4 a was not supported.

In contrast, as Hypothesis 4b predicted for mastery, group evaluation interacted with closeness. This interaction is shown graphically in Figure 1. For respondents who scored one standard deviation below the mean on group evaluation (shown by the diamond-marked line), closeness decreased mastery. Though not predicted by Hypothesis $4 \mathrm{~b}$, the analysis also shows that closeness increased mastery for respondents who scored one standard deviation above the mean on group evaluation (the triangle-marked line). Using Aiken and West's (1991) procedure to test the statistical significance of the simple slopes, we found that none of the three regressions lines graphed in Figure 1 was statistically significant. However, higher closeness was associated with significantly lower mastery for respondents who evaluated their ingroup very unfavorably, at about 1.7 standard deviations below the mean (a score of 1.35 on the index). And higher closeness was associated with higher mastery for respondents who were 1.5 standard deviations above the mean on group evaluation (a score of 2.9 on the index).

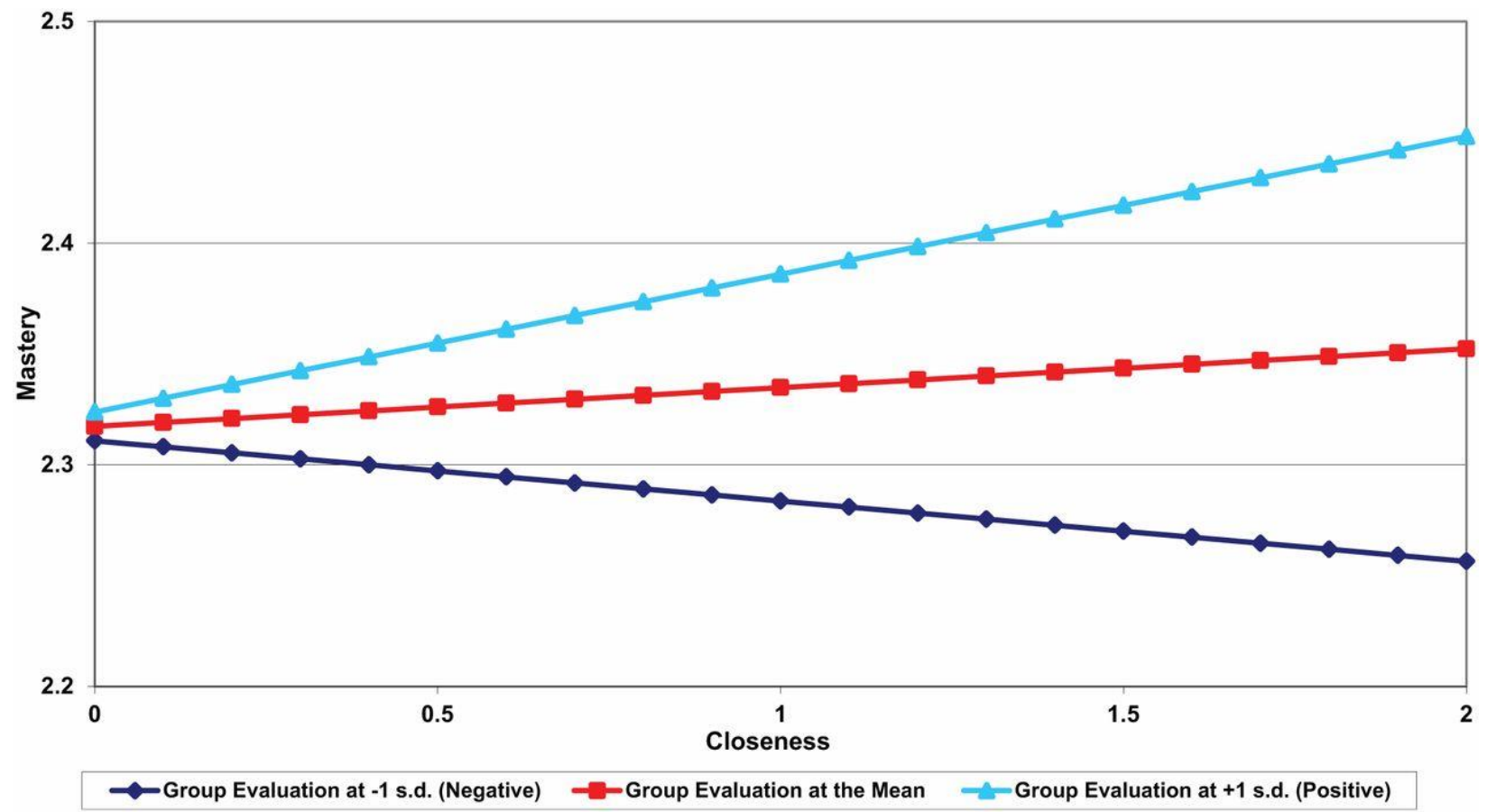

Figure 1. Mastery by Closeness at Three Levels of Group Evaluation 
Put differently, for respondents who felt closer to other African Americans - those whose scores fell on the right side of Figure 1-group evaluation was a strong predictor of mastery. For respondents who did not feel very close - those whose scores fell on the left side of Figure 1group evaluation was unrelated to mastery, as shown by the negligible differences among the lines. Group evaluation was a significant positive predictor of mastery over most of the range of closeness, at or above a score of .68 or about 1.24 standard deviations below the mean on closeness.

Model III shows that closeness and group evaluation also interacted to influence depressive symptoms, as Hypothesis 4c predicted (see Figure 2). For respondents who scored one standard deviation below the mean on group evaluation (shown by the diamond-marked line), closeness increased depressive symptoms. Though not predicted by Hypothesis $4 \mathrm{c}$, the analysis also shows that for respondents who scored one standard deviation above the mean on group evaluation (shown by the triangle-marked line), closeness decreased depressive symptoms. As described previously, we used Aiken and West's (1991) procedure for testing the statistical significance of the three simple slopes. Only the top one, which depicts the association of closeness and depressive symptoms for respondents with a less favorable ingroup evaluation (a score of 1.69 on the index), was significant. In analyses not shown, however, closeness significantly decreased symptoms for respondents who scored 1.5 standard deviations above the mean on group evaluation (a score of 2.9).

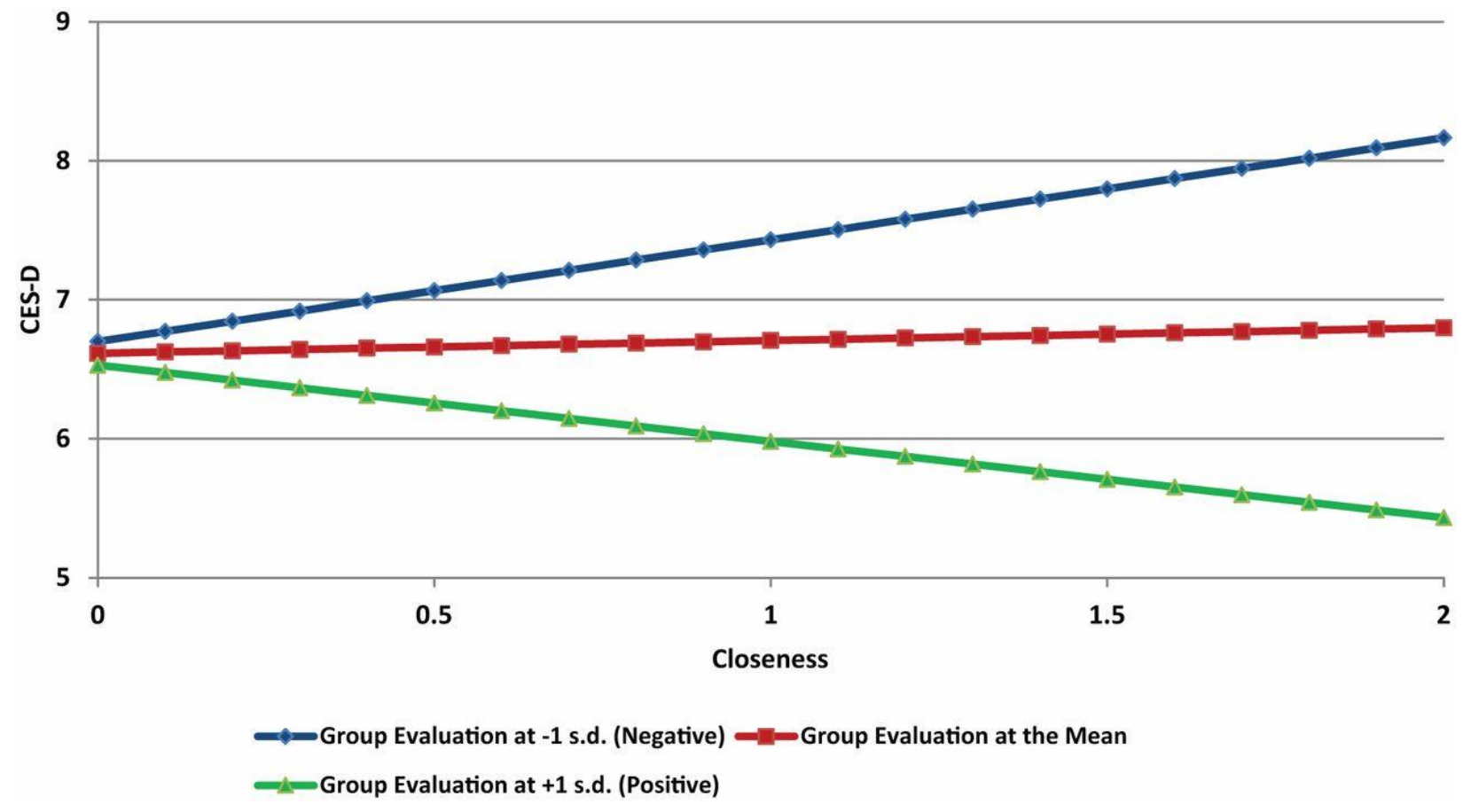

Figure 2. Depressive Symptoms (CES-D) by Closeness at Three Levels of Group Evaluation Figure 2 also shows that at higher levels of closeness, group evaluation was more strongly associated with depressive symptoms. The lines differed markedly on the right side of the figure 
but negligibly on the left side. Group evaluation significantly predicted depressive symptoms over most of the range of closeness. It became significant at about 1.55 standard deviations below the mean on closeness (a score of .52).

\section{Discussion}

This study re-examined a long-standing question — how racial identity affects African Americans' self-attitudes and well-being-by evaluating the competing claims of social identity theory (e.g., Tajfel and Turner 1986) and the internalized racism perspective (e.g., Lewin 1948; Proshansky and Newton 1968;Williams and Mohammed 2013). We find that both frameworks are necessary for understanding how racial identity is related to self-attitudes and mental health among African Americans.

Our findings supported three hypotheses derived from social identity theory. First, the more closely African Americans identified with their group, the more positively they evaluated it. Second, racial group identification was associated with higher self-esteem and mastery and lower depressive symptoms. Third, positive ingroup evaluation also was related to more positive selfattitudes (self-esteem and mastery) and lower depressive symptoms.

We drew on the internalized racism perspective to address a question that research on social identity theory has not directly examined-how well-being is affected when people cannot achieve a positive social identity. What happens to self-esteem, mastery, or psychological wellbeing when people negatively evaluate and identify with their group but can neither leave it nor increase its status? This combination of strong identification and negative evaluation implies that social creativity strategies have failed. As the internalized racism perspective would predict, when that was the case, racial identification with other African Americans was associated with lower mastery and higher depressive symptoms.

Our study shows that most African Americans achieve a positive social identity by strongly identifying with their racial group and viewing it very positively and that these elements promote and maintain self-worth, self-efficacy, and good mental health. However, finding that identification results in lower mastery and higher depressive symptoms among those who evaluate their group negatively suggests that the identity processes emphasized by the internalized racism perspective (Lewin 1948; Meyer 2003), though less common than might be assumed (Williams and Mohammad 2013), are real and potentially detrimental to African Americans' well-being.

Finding that most African Americans closely identify with their group and view it very positively indicates that racial identity has a net positive impact on African Americans' mental health, a conclusion strengthened by the unexpected finding that when group evaluation was positive (which was most common among respondents), closeness increased mastery and decreased depressive symptoms. These findings may help explain African Americans' high positive selfattitudes and overall good mental health (Breslau et al. 2006; Gray-Little and Hafdahl 
2000; Rosenberg and Simmons 1972). However, our findings supporting the internalized racism perspective suggest that cultural processes that promote negative stereotypes can undermine this mental-health advantage.

Our study has three potentially significant limitations. First, the data are cross-sectional, so we could not determine whether identity dimensions influence well-being or the reverse. Second, other measures of racial identity would have been desirable. For example, the measure of racial centrality that we dropped from the analysis because it was unrelated to well-being may have been inadequate. Measures of both absolute and multiple comparative judgments of racial identity centrality (Ashmore et al. 2004) would provide a better test. Third, we could not fully test the self-esteem hypothesis in social identity theory because the data set did not contain outgroup evaluations. Nevertheless, our findings were consistent with the first corollary (Abrams and Hogg 1988) of the self-esteem hypothesis.

We emphasize four significant questions that should be addressed in future research. First, as just noted, it is unclear from our analysis whether making favorable comparisons at the expense of outgroups would have been more beneficial in boosting positive self-attitudes and mental health. Research is needed on the question of whether ingroup bias or positive ingroup evaluation better mediates the relationship between group identification and well-being.

Second, research should more carefully examine how different ways of conceptualizing and measuring social identity affect perceptions of discrimination. Our findings showing no association of group evaluation parallel those of other studies (Branscombe et al. 1999; Ramos et al. 2012; Sellers and Shelton 2003), but our finding that racial identification (closeness) is not related to reported everyday racial discrimination is unexpected. These results may differ from those of previous studies because of differences in our measurement of racial identification or because of the nature of our sample.

Third, research is needed to understand our finding that social relationships partly mediate the association between racial identity variables and well-being (as suggested by the work of Haslam et al. 2009). Because identity theory proposes that well-being rests partly on identity verification from role partners with whom people have affective ties (Burke and Stets 2009), a more complete understanding of how social ties mediate the association between identity and wellbeing may require further integrating social identity theory and identity theory (Deaux and Burke 2010; Deaux and Martin 2003). It may also be fruitful to consider the proximate social structures in which those ties form (Merolla et al. 2012). How and when positive racial identities are verified by role partners in proximate social structures and how racial and role identities intertwine are important issues to explore.

Finally, future research should further investigate how and when racial identity buffers stressors. For example, racial identity buffers the effects of financial stress on depressive symptoms (Hughes, Kiecolt, and Keith 2014), but the evidence concerning perceived discrimination is 
mixed. Some studies find that racial identity protects against adverse effects of discrimination on mental health (e.g., Mossakowski 2003; Sellers et al. 2003); others report that racial identity exacerbates the effects of discrimination; and most studies detect no significant moderation effects (reviewed by Brondolo et al. [2006] and Pascoe and Richman [2009]).

In recent decades, researchers have investigated a wealth of racial identity dimensions (e.g., Phinney 1991; Sellers et al. 1998) and have emphasized how racial identity develops (e.g., Cross 1991; Vandiver 2001; Vandiver et al. 2002) and how it relates to well-being (e.g., Ida and Christie-Mizell 2012; Sellers et al. 2003). We believe that our study demonstrates the benefits of theoretically grounded research on racial identity and its consequences, and we suggest that social identity theory, identity theory, and the internalized racism perspective may

provide fruitful paths for further elucidating the psychological and social processes that maintain positive and beneficial racial identities over the life course

In conclusion, our study shows the value of combining social identity theory with the internalized racism perspective to explain how racial identity influences well-being among African Americans. The benefits of racial identity that social identity theory emphasizes are real, but so are the cultural and structural forces that can undermine those benefits.

\section{Acknowledgments}

An earlier version of this paper was presented at the Annual Meeting of the American Sociological Association in Atlanta, GA, August 2010. We thank Danny Axsom, Rachelle Brunn, Kenya King, and Carolyn J. Kroehler for comments on an earlier draft.

\section{Notes}

1 Self-categorization theory, "the cognitive dimension of the social identity approach, describes how categorization of self and other underpins social identification" (Hogg 2006:113) and grouplevel phenomena such as group cohesiveness, social stereotyping, shared norms, and social influence processes (Thoits and Virshup 1997).

2 They also may compare themselves to ingroup members rather than outgroup members or attribute negative societal evaluation of the ingroup to outgroup prejudice or racism (Crocker and Major 1989).

3 Other proposed functions of identities include self-knowledge, meaning, and uncertainty reduction (Hogg and Abrams 1990). Group membership and identification can also help satisfy needs for both belonging and distinctiveness (being different from others), as Brewer's (1991) optimal distinctiveness theory predicts.

4 Cross (1991) used the term "personal identity" to refer to a broad category of personal characteristics, including self-esteem, self-confidence, self-evaluation, interpersonal competence, personality traits, and level of anxiety. Contemporary scholarship refers instead to self-attitudes 
(e.g., self-esteem and mastery) and well-being (e.g., distress). The term personal identity now usually refers to perceived traits or behavioral tendencies (e.g., creativity).

5 Vandiver et al. (2002) reported scores on self-hatred scales for two independent samples. Average scores were low (about 2 on a scale from 1 to 7 ), and the proportion of respondents scoring high in self-hatred was very small.

6 The evidence for racial outgroup preference was weak or of dubious validity (reviewed by Cross 1991). Most studies were conducted with children (e.g., Clark and Clark's [1947] doll studies); one sampled 25 adults, most of whom were in psychotherapy (Kardiner and Ovesey 1951); and one classic essay did not cite any studies at all (Proshansky and Newton 1968). Cross also notes that no empirical studies from 1940 to 1960 examined whether black group identity was associated with personal well-being, including self-esteem.

7 Similarly, Meyer (1995) showed that internalized homophobia (in his study, gay men's negative evaluation of being gay) strongly predicted poor mental health, but most gay men scored low on it.

8 Feelings about particular others (e.g., relatives and friends) can generalize to feelings about the others' social category via affective commitment to others' role identities (Deaux and Martin 2003; Lawler 2003). Conversely, chronic negative interactions with role partners should weaken group identification (Cast and Burke 2002; Deaux and Martin 2003). Social relationships also may promote racial identification through everyday discussions of African Americans' concerns. In churches, exposure to political messages fosters a sense of commonality with other African Americans (Calhoun-Brown 1996). In families, racial socialization by parents shapes their children's racial identity (Demo and Hughes 1990; Neblett et al. 2013).

9 Initial analyses also included two other dimensions of racial identity. Identity centrality was measured by asking, "Which would you say is more important to you-being black or being American, or are both equally important to you?" A dichotomous variable, "being black" versus the other responses, was unrelated to any of the measures of well-being, and it was related to only one other identity dimension (common fate; $r=.06$ ). Perceived common fate with black Americans was measured by asking, "Do you think what happens generally to black people in this country will have something to do with what happens in your life?" $(1=$ yes; $0=$ no $)$. Common fate also was unrelated to well-being but was slightly related to closeness $(r=.06)$ and group evaluation $(r=.11)$. As neither identity dimension was related to well-being among African Americans, we dropped them from the analysis.

10 In analyses not shown, we also estimated models that controlled for lifetime racial discrimination. It, too, was uncorrelated with the racial identity variables, and it was less strongly correlated with the measures of well-being. 


\section{Bios}

Michael Hughes is a professor of sociology at Virginia Tech and a faculty affiliate of the Virginia Tech Africana Studies program. His main research interests include mental health/illness, ethnic and racial identity, racial attitudes, and patterns of cultural choice. Recent articles have appeared in Society and Mental Health, Psychological Trauma: Theory, Research, Practice, and Policy, and The Annals of the American Academy of Political and Social Science. With Carolyn J. Kroehler he is author of Sociology: The Core (2013).

K. Jill Kiecolt is an associate professor in the Department of Sociology at Virginia Tech and a faculty affiliate of the Virginia Institute of Psychiatric and Behavioral Genetics at Virginia Commonwealth University. Her research focuses on self and identity processes and their contributions to mental health and well-being and more recently, genetic and environmental influences on the stress process. Her work has appeared in Social Psychology Quarterly, Journal of Health and Social Behavior, Society and Mental Health, and Journal of Marriage and Family.

Verna M. Keith is a professor of sociology and director of the Race and Ethnic Studies Institute at Texas A\&M University. Her research interests include the impact of subjective experiences of discrimination on mental health and the effects of ethnic appearance on the social, economic, and psychological well-being of African Americans and other people of color. She is editor of In and Out of Right Minds: The Mental Health of African American Women, with Diane Brown, and she is a coauthor of "Poverty, Education, Racial Discrimination and Depressive Symptoms among African Americans: Testing Exposure and Vulnerability Hypotheses" in Society and Mental Health (2013).

David H. Demo is a professor in the department of Human Development and Family Studies and Associate Dean for Graduate Programs in the School of Health and Human Sciences at the University of North Carolina at Greensboro. His research focuses on divorce and family transitions, changes in family relationships accompanying divorce, and the consequences of family transitions for parents' and children's well-being.

\section{References}

1. Abrams Dominic, Hogg Michael A. 1988. "Comments on the Motivational Status of SelfEsteem in Social Identity and Intergroup Discrimination.”European Journal of Social Psychology 18:317-34.

2. Aiken Leona S., West Stephen G. 1991. Multiple Regression: Testing and Interpreting Interactions. Newbury Park, CA: Sage Publications.

3. Alegria Margarita, Jackson James S., Kessler Ronald C., Takeuchi David. 2007. Collaborative Psychiatric Epidemiology Surveys (CPES), 20012003 [United States] [Computer file]. ICPSR20240-v2. Ann Arbor, MI: Institute for Social 
Research, Survey Research Center [producer]. Ann Arbor, MI: Inter-university Consortium for Political and Social Research [distributor].

4. Ashmore Richard D., Deaux Kay, McLaughlin-Volpe Tracy. 2004. "An Organizing Framework for Collective Identity: Articulation and Significance of Multidimensionality." Psychological Bulletin 130:80114.Blanz Matthias, Mummendey Amélie, Mielke Rosemarie, Klink Andreas. 1998. "Responding to Negative Social Identity: A Taxonomy of Identity Management Strategies.” European Journal of Social Psychology 28:697-729.

5. Branscombe Nyla R., Schmitt Michael T., Harvey Richard D. 1999. "Perceiving Pervasive Discrimination Among African Americans: Implications for Group Identification and WellBeing." Journal of Personality and Social Psychology 77:135-49.

6. Breslau Joshua, Aguilar-Gaxiola Sergio, Kendler Kenneth S., Su Maxwell, Williams David, Kessler Ronald C. 2006. "Specifying Race-Ethnic Differences in Risk for Psychiatric Disorder in a USA National Sample.” Psychological Medicine: A Journal of Research in Psychiatry and the Allied Sciences 36:57-68

7. Brewer Marilynn B. 1991. "The Social Self: On Being the Same and Different at the Same Time.” Personality and Social Psychology Bulletin 17:475-82.

8. Brewer Marilynn B. 2007. "The Importance of Being We: Human Nature and Intergroup Relations.” American Psychologist 62:728-38.

9. Broman Clifford L., Neighbors Harold W., Jackson James S. 1988. "Racial Group Identification Among Black Adults." Social Forces 67:146-58.

10. Brondolo Elizabeth, ver Halen Nisha Brady, Pencille Melissa, Beatty Danielle, Contrada Richard J. 2009. "Coping with Racism: A Selective Review of the Literature and Methodological Critique.” Journal of Behavioral Medicine 32:64-88.

11. Brown Rupert. 2000. "Social Identity Theory: Past Achievements, Current Problems, and Future Challenges.” European Journal of Social Psychology30:745-78.

12. Brown Tony, Sellers Sherrill L., Gomez John P. 2002. "The Relationship Between Internalization and Self-Esteem Among Black Adults.” Sociological Focus 35:55-71.

13. Burke Peter J., Stets Jan E. 2009. Identity Theory. New York: Oxford University Press.

14. Caldwell Cleopatra Howard, Zimmerman Marc A., Bernat Debra Hilkene, Sellers Robert M., Notaro Paul C. 2002. "Racial Identity, Maternal Support, and Psychological Distress Among African American Adolescents." Child Development 73:1322-36. 
15. Calhoun-Brown Allison. 1996. “African American Churches and Political Mobilization: The Psychological Impact of Organizational Resources.” Journal of Politics 58:935-53.

16. Cast Alicia D., Burke Peter J. 2002. “A Theory of Self-Esteem.” Social Forces 80:1041-68.

17. Clark Kenneth B., Clark Mamie P. 1947. "Racial Identification and Preference in Negro Children.” Pp. 168-78 in Readings in Social Psychology, edited byNewcomb T. M., Hartley E. L. New York: Holt.

18. Crocker Jennifer, Major Brenda. 1989. "Social Stigma and Self-Esteem: The Self-Protective Properties of Stigma.” Psychological Review 96:608-30.

19. Cross William E. Jr. 1971. “The Negro to Black Conversion Experience.” Black World 20:13-27.

20. Cross William E. Jr. 1991. Shades of Black: Diversity in African-American Identity. Philadelphia, PA: Temple University Press.

21. Deaux Kay. 1993. "Reconstructing Social Identity." Personality and Social Psychology Bulletin 19:4-12.

22. Deaux Kay, Burke Peter J. 2010. "Bridging Identities.” Social Psychology Quarterly 73:31520.

23. Deaux Kay, Martin Daniela. 2003. "Interpersonal Networks and Social Categories: Specifying Levels of Context in Identity Processes.” Social Psychology Quarterly 66:101-17.

24. Demo David H., Hughes Michael. 1990. "Socialization and Racial Identity Among Black Americans.” Social Psychology Quarterly 53:364-74.

25. Ellemers Naomi, Haslam S. Alexander. 2012. "Social Identity Theory.” Pp. 37998 in Handbook of Theories of Social Psychology, edited by Van Lange P. A. M., Kruglanski A. W., Higgins E. T. Los Angeles, CA: Sage.

26. Ellemers Naomi, Kortekass Paulien, Ouwerkerk Jaap W. 1999. "Self-Categorization, Commitment to the Group and Group Self-Esteem as Related but Distinct Aspects of Social Identity." European Journal of Social Psychology 29:371-89.

27. Gray-Little Bernadette, Hafdahl Adam R. 2000. "Factors Influencing Racial Comparisons of Self-Esteem: A Quantitative Review.” Psychological Bulletin126:26-54.

28. Harris David. 1995. "Exploring the Determinants of Adult Black Identity: Context and Process.” Social Forces 74:227-41. 
29. Haslam S. Alexander, Jetten Jolanda, Postmes Tom, Haslam Catherine. 2009. "Social Identity, Health, and Well-Being: An Emerging Agenda for Applied Psychology." Applied Psychology 58:1-23.

30. Haslam S. Alexander, O’Brien Anne, Jetten Jolanda, Vormedal Karine, Penna Sally. 2005. "Taking the Strain: Social Identity, Social Support, and the Experience of Stress." British Journal of Social Psychology 44:355-70.

31. Heeringa Steven G., Wagner James, Torres Miriam, Duan Naihua, Adams Terry, Berglund Patricia . 2006. "Sample Designs and Sampling Methods for the Collaborative Psychiatric Epidemiology Studies (CPES).” International Journal of Methods in Psychiatric Research 13:221-40.

32. Hinkle Steve, Brown Rupert. 1990. "Intergroup Comparisons and Social Identity: Some Links and Lacunae." Pp. 48-70 in Social Identity Theory: Constructive and Critical Advances, edited by Abrams D., Hogg M. New York: Springer-Verlag.

33. Hinkle Steve, Taylor Laurie A., Fox-Cardamone D. Lee, Crook Kimberly F. 1989. "Intragroup Discrimination and Intergroup Discrimination: A Multicomponent Approach.” British Journal of Social Psychology 28:305-17.

34. Hogg Michael. 2006. "Social Identity Theory." Pp. 111-36 in Contemporary Social Psychological Theories, edited by Burke P. J. Stanford, CA: Stanford Social Sciences.

35. Hogg Michael, Abrams Dominic. 1990. "Social Motivation, Self-Esteem, and Social Identity." Pp. 28-47 in Social Identity Theory: Constructive and Critical Advances, edited by Abrams D., Hogg. M. A. Hemel Hempstead, England: Harvester Wheatsheaf.

36. Houston Diane M., Andreopoulou Alexis. 2003. "Tests of Both Corollaries of Social Identity Theory's Self-Esteem Hypothesis in Real Group Settings.'British Journal of Social Psychology 42:357-70.

37. Hughes Michael, Demo David H. 1989. "Self-Perceptions of Black Americans: Self-Esteem and Personal Efficacy." American Journal of Sociology95:132-59.

38. Hughes Michael, K., Kiecolt Jill, Keith Verna M. 2014. "How Racial Identity Moderates the Impact of Financial Stress on Mental Health Among African Americans." Society and Mental Health 4:38-54.

39. Ida Aya Kimura, Christie-Mizell C. André. 2012. "Racial Group Identity, Psychosocial Resources, and Depressive Symptoms: Exploring Ethnic Heterogeneity Among Black Americans." Sociological Focus 45:41-62.

40. Jackson James S., Torres Miriam, Caldwell Cleopatra H., Neighbors Harold W., Nesse Randolph M., Taylor Robert Joseph, Trierweiler Steven J., Williams David R. 
2006. "The National Survey of American Life: A Study of Racial, Ethnic, and Cultural Influences on Mental Disorders and Mental Health.'International Journal of Methods in Psychiatric Research 13:196-207.

41. Jackson Jay W. 2002. "Intergroup Attitudes as a Function of Different Dimensions of Group Identification and Perceived Intergroup Conflict." Self and Identity 1:11-33.

42. Jackson Jay W., Smith Eliot R. 1999. "Conceptualizing Social Identity: A New Framework and Evidence for the Impact of Different Dimensions."Personality and Social Psychology Bulletin 25:120-35.

43. Kardiner Abram, Ovesey Lionel. 1951. The Mark of Oppression. New York: Norton.

44. Kessler Ronald C., McGonagle Katherine A., Zhao Shanyang, Nelson Christopher B., Hughes Michael, Eshleman Suzann, Wittchen Hans-Ulrich, Kendler Kenneth S. 1994. "Lifetime and 12-Month Prevalence of DSM-III-R Psychiatric Disorders in the United States: Results from the National Comorbidity Study." Archives of General Psychiatry 51:8-19.

45. Kessler Ronald C., Mickelson Kristin D., Williams David R. 1999. "The Prevalence, Distribution, and Mental Health Correlates of Perceived Discrimination in the United States" Journal of Health and Social Behavior 40:208-30.

46. Kiecolt K. Jill, Hughes Michael, Keith Verna M. 2008. "Race, Social Relationships, and Mental Health." Personal Relationships 15:229-45.

47. Kiecolt K., Michael Hughes Jill, M. Keith Verna. 2009. "Can a High Sense of Control and John Henryism Be Bad for Mental Health?” The Sociological Quarterly 50:693-714.

48. Lawler Edward J. 2003. "Interaction, Emotion, and Collective Identities." Pp. 13550 in Advances in Identity Theory and Research, edited by Burke P. J.,Owens T. J., Serpe R. T., Thoits P. A. New York: Kluwer Academic/Plenum.

49. Levy Becca R., Zonderman Alan B., Slade Martin D., Ferrucci Luigi. 2009. "Age Stereotypes Held Earlier in Life Predict Cardiovascular Events in Later Life." Psychological Science 20:296-98.

50. Lewin Kurt. 1948. Resolving Social Conflicts. New York: Harper.

51. Link Bruce G. 1987. "Understanding Labeling Effects in the Area of Mental Disorders: An Assessment of the Effects of Expectations of Rejection."American Sociological Review 52:96-112.

52. Mabry J. Beth, Kiecolt K. Jill. 2005. "Anger in Black and White: Race, Alienation, and Anger." Journal of Health and Social Behavior 46:85-101. 
53. McCarthy John D., Yancey William L. 1971. "Uncle Tom and Mr. Charlie: Metaphysical Pathos in the Study of Racism and Personal Disorganization."American Journal of Sociology 76:648-72.

54. Merolla David M., Serpe Richard T., Stryker Sheldon, Schultz P. Wesley. 2012. "Structural Precursors to Identity Processes: The Role of Proximate Social Structures." Social Psychology Quarterly 75:149-72.

55. Meyer Ilan H. 1995. "Minority Stress and Mental Health in Gay Men." Journal of Health and Social Behavior 36:38-56.

56. Meyer Ilan H. 2003. "Prejudice, Social Stress, and Mental Health in Lesbian, Gay, and Bisexual Populations: Conceptual Issues and Research Evidence.”Psychological Bulletin 129:674-97.

57. Miller Byron, Rote Sunshine M., Keith Verna M. 2013. "Coping with Racial Discrimination: Assessing the Vulnerability and the Mediated Moderation of Psychosocial Resources." Society and Mental Health 3:133-50.

58. Montazer Shirin, Wheaton Blair. 2011. "The Impact of Generation and Country of Origin on the Mental Health of Children of Immigrants." Journal of Health and Social Behavior 52:2342.

59. Mossakowski Krysia N. 2003. “Coping with Perceived Discrimination: Does Ethnic Identity Protect Mental Health?” Journal of Health and Social Behavior44:318-31.

60. Mossakowski Krysia N. 2007. "Are Immigrants Healthier? The Case of Depression Among Filipino Americans.” Social Psychology Quarterly 70:290-304.

61. Mummendey Amélie, Kessler Thomas, Klink Andreas, Mielke Rosemarie. 1999. "Strategies to Cope with Negative Social Identity: Social Identity Theory and Relative Deprivation Theory." Journal of Personality and Social Psychology 76:229-45.

62. Neblett Enrique W. Jr., Banks Kira Hudson, Cooper Shauna M., Smalls-Glover Ciara. 2013. "Racial Identity Mediates the Association Between Ethnic-Racial Socialization and Depressive Symptoms.” Cultural Diversity and Ethnic Minority Psychology 19:200-207.

63. Okun Morris A., Keith Verna M. 1998. "Effects of Positive and Negative Social Exchanges with Various Sources on Depressive Symptoms in Younger and Older Adults." Journals of Gerontology: Psychological Sciences 53B:P4-P20.

64. Outten H. Robert, Schmitt Michael T., Garcia Donna M., Branscombe Nyla R. 2009. "Coping Options: Missing Links Between Minority Group Identification and Psychological Well-Being. Applied Psychology: An International Review 58:146-70. 
65. Pascoe Elizabeth A., Richman Laura Smart. 2009. "Perceived Discrimination and Health: A Meta-Analytic Review.” Psychological Bulletin 135:531-54.

66. Pearlin Leonard I., Clarice W. Radabaugh 1976. "Economic Strains and the Coping Functions of Alcohol.” American Journal of Sociology 82:652-63.

67. Phinney Jean. 1991. "Ethnic Identity and Self-Esteem: A Review and Integration.” Hispanic Journal of Behavioral Sciences 13:193-208.

68. Porter Judith R., Washington Robert E. 1979. "Black Identity and Self-Esteem: A Review of Studies of Black Self-concept, 1968-1978.” Annual Review of Sociology 5:53-74.

69. Postmes Tom, Branscombe Nyla. 2002. "Influence of Long-Term Racial Environmental Composition on Subjective Well-Being in African Americans."Journal of Personality and Social Psychology 83:735-51.

70. Proshansky Harold, Newton Peggy. 1968. "The Nature and Meaning of Negro Self-Identity." Pp. 178-218 in Social Class, Race, and Psychological Development, edited by Deutsch M., Katz I., Jensen A. R. New York: Holt, Rinehart, and Winston.

71. Radloff Lenore S. 1977. "The CES-D Scale: A Self-Report Depression Scale for Research in the General Population.” Applied Psychological Measurement 1:385-401.

72. Ramos Miguel R., Cassidy Clare, Reicher Stephen, Haslam S. Alexander. 2012. “A Longitudinal Investigation of the Rejection-Identification Hypothesis."British Journal of Social Psychology 51:642-60.

73. Rosenberg Morris. 1979. Conceiving the Self. New York: Basic Books.

74. Rosenberg Morris. 1989. Society and the Adolescent Self-Image. Revised edition. Middletown, CT: Wesleyan University Press.

75. Rosenberg Morris, Simmons Roberta G. 1972. Black and White Self-Esteem: The Urban School Child. Washington, DC: American Sociological Association.

76. Rowley Stephanie J., Sellers Robert M., Chavous Tabbye M., Smith Mia A. 1998. "The Relationship Between Racial Identity and Self-Esteem in African American College and High School Students.” Journal of Personality and Social Psychology 74:715-24.

77. Rubin Mark, Hewstone Miles. 1998. "Social Identity Theory's Self-Esteem Hypothesis: A Review and Some Suggestions for Clarification." Personality and Social Psychology Review 2:40-62. 
78. Sellers Robert M., Caldwell Cleopatra H., Schmeelk-Cone Karen H., Zimmerman Marc A. 2003. "Racial Identity, Racial Discrimination, Perceived Stress, and Psychological Distress Among African American Young Adults.” Journal of Health and Social Behavior 43:302-17.

79. Sellers Robert M., Shelton J. Nicole. 2003. "The Role of Racial Identity in Perceived Racial Discrimination.” Journal of Personality and Social Psychology84:1079-92.

80. Sellers Robert M., Smith Mia A., Shelton J. Nicole, Rowley Stephanie A. J., Chavous Tabbye M. 1998. "Multidimensional Model of Racial Identity: A Reconceptualization of African American Racial Identity.” Personality and Social Psychology Review 2:18-39.

81. Smith Timothy B., Silva Lynda. 2011. "Ethnic Identity and Personal Well-Being of People of Color: A Meta-Analysis.” Journal of Counseling Psychology 58:42-60.

82. StataCorp. 2011. Stata Statistical Software: Release 12. College Station, TX: StataCorp LP.

83. Steele Claude. 1997. "A Threat in the Air: How Stereotypes Shape Intellectual Identity and Performance." American Psychologist 52:613-29.

84. Stets Jan E., Burke Peter J. 2000. “Identity Theory and Social Identity Theory.” Social Psychology Quarterly 63:224-37.

85. Stuber Jennifer, Meyer Ilan, Link Bruce. 2008. "Stigma, Prejudice, Discrimination, and Health. Social Science and Medicine 67:351-57.

86. Tajfel Henri. 1978. "Social Categorization, Social Identity and Social Comparison.” Pp. 6176 in Differentiation Between Social Groups: Studies in the Social Psychology of Intergroup Relations, edited by Tajfel H. London: Academic Press.

87. Tajfel Henri, Turner John C. 1986. "The Social Identity Theory of Inter-Group Behavior." Pp. 2-24 in Psychology of Intergroup Relations, edited by Worchel S., Austin L. W. Chicago: Nelson-Hall.

88. Thoits Peggy A. 2013. "Self, Identity, Stress, and Mental Health.” Pp. 357-77 in Handbook of the Sociology of Mental Health. 2nd ed., edited byAneshensel C. S., Phelan J. C., Bierman A. New York: Springer.

89. Thoits Peggy A., Virshup Lauren K. 1997. “Me’s and We's: Forms and Functions of Social Identities." Pp. 106-33 in Self and Identity: Fundamental Issues, edited by Ashmore R. D., Jussim L. New York: Oxford University Press.

90. Turner R. Jay, Avison William R. 2003. "Status Variations in Stress Exposure: Implications for the Interpretation of Research on Race, Socioeconomic Status, and Gender." Journal of Health and Social Behavior 44:488-505. 
91. Vandiver Beverly J. 2001. "Psychological Nigrescence Revisited: Introduction and Review." Journal of Multicultural Counseling and Development29:165-73.

92. Vandiver Beverly J., Cross William E. Jr., Worrell Frank C., Fhagen-Smith Peony E. 2002. "Validating the Cross Racial Identity Scale." Journal of Counseling Psychology 49:71-85.

93. Vignoles Vivian L., Regalia Camillo, Manzi Claudia, Golledge Jen, Scabini Eugenia. 2006. "Beyond Self-Esteem: Influence of Multiples Motives on Identity Construction." Journal of Personality and Social Psychology 90:308-33.

94. Williams David R., Haile Rahwa, Mohammed Selina A., Herman Allen, Stein Dan J., Sonnega John, Jackson James S. 2012. "Perceived Discrimination and Psychological Well-Being in the U.S. and South Africa." Ethnicity \& Health 17:111-33.

95. Williams David R., Mohammed Selina A. 2013. "Racism and Health I: Pathways and Scientific Evidence.” American Behavioral Scientist 57:1152-73.

96. Williams David R., Yu Yan, Jackson James S., Anderson Norman B. 1997. "Racial Differences in Physical and Mental Health: Socio-Economic Status, Stress, and Discrimination." Journal of Health Psychology 2:335-51.

97. Yancey William L., Rigsby Leo, McCarthy John D. 1972. "Social Position and SelfEvaluation: The Relative Importance of Race.” American Journal of Sociology 78:338-59. 